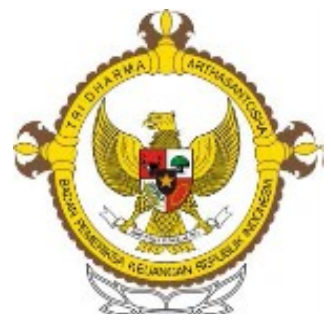

JURNAL

TATA KELOLA \& AKUNTABILITAS KEUANGAN NEGARA

Volume 5, Number 1, Jan-Jun 2019, 91-101

e-ISSN 2549-452X

p-ISSN 2460-3937

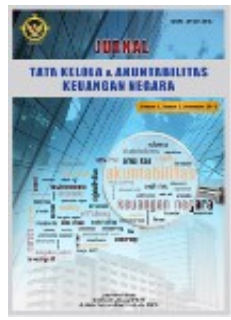

\title{
MEASURING EFFICIENCY AND EFFECTIVENESS OF INDONESIAN REGIONAL DEVELOPMENT BANKS
}

\author{
Bahrullah Akbar ${ }^{1}$, Achmad Djazuli $^{2}$, and Jariyatna ${ }^{3}$ \\ Institut Pemerintahan Dalam Negeri ${ }^{1}$ \\ Sekolah Tinggi Ekonomi Islam Tazkia ${ }^{2}$ \\ Badan Pemeriksa Keuangan Republik Indonesia ${ }^{3}$ \\ Bahrullah314@gmail.com ${ }^{1}$,Djazulidevi97@gmail.com², Jariyatna@bpk.go.id ${ }^{3}$
}

\section{ABSTRACT}

This study explores the efficiency and effectiveness of Regional Development Banks (BPD) based on the results of performance audit conducted by the Audit Board of the Republic of Indonesia (BPK RI). Performance audit produces conclusion and recommendation on economy, efficiency and effectiveness (3E). BPDs are expected to be regional champions in their respective regions. Data envelopment analysis (DEA) is used to calculate the level of production and operational efficiency of the BPDs while the level of effectiveness is assessed based on the results of performance audit conducted by BPK RI. The results show that both efficiency and effectiveness are not always achieved. This study also identifies BPD that have the highest value of production and operational efficiency and the level of effectiveness. The BPD obtained the highest efficiency and effectiveness values that could be used as a reference for other BPDs to make improvements and become a regional champion in their respective regions.

KEYWORDS:

Data envelopment analysis (DEA); production efficiency; operational efficiency; effectiveness 


\section{INTRODUCTION}

Based on the article $23 \mathrm{E}$ of the 1945 Constitution (UUD 1945), the Audit Board of the Republic Indonesia (BPK RI) is given a mandate to audit the management and responsibility of state finance. According to the article 15 of the Law Number 15 of 2004 on the Audit of Management and Responsibility of State Finance, the audit conducted by BPK consists of financial statements audit, performance audit, and special purpose audit. Based on this regulation, BPK has authority to conduct performance audit on the central government, local governments (provincial, regency, and city), StateOwned Enterprises (BUMN), and Local Government-Owned Enterprises (BUMD).

BUMD is a business entity which the local government has majority ownership. According to Local Regulations (Perda), BUMDs can be in the form of limited corporations (Perseroan Terbatas) and local company (Perusahaan Daerah). The objectives of BUMD are to produce profit and provide economic benefits for local economic development. The number of BUMD according to Financial Statistics of State Owned Enterprises and Regional Owned Enterprises 2017 of Statistics Indonesia is about 782 BUMDs, consist of 115 BUMDs owned by provincial goverments and 667 BUMDs owned by regency and city goverments (Statistics Indonesia, 2018). There are 16 types of businesses of BUMD such as financial services, trading, transportation, and others (Statistics Indonesia, 2018).

One form of BUMD business at the provincial level is Regional Development Bank (BPD). There are 26 BPDs throughout Indonesia. As of May 2018, BPD assets have reached Rp649.19 trillion or increased by 5\% compared to the position in May 2017 on Rp618.26 trillion. In May 2018, BPD's loan position reached Rp401.53 trillion, an increase of $9.28 \%$ compared to the position in May 2017 of Rp367.42 trillion. While the position of the Third Party Funds (DPK) of BPD throughout Indonesia in May 2018 reached Rp517.12 trillion, or increased by 2.53\% compared to the position in May 2017 of Rp504.34 trillion (Investor Daily Indonesia, August 2018).

BPD is expected to support local economic growth. Bank Indonesia had issued the BPD Regional Champion (BRC) as the initiation of increasing the role of the BPD for local economic growth and strengthening the national banking structure. The BRC consists of three main pillars, namely (1) maintaining and improving banking resilience; (2) the role of agent of local development; and (3) improvement of the ability to serve the community, especially in the regions (Investor Daily Indonesia, 2018). While the The Financial Services Authority (OJK) in 2015 also issued a BPD transformation program, which consisted of: (1) increased competitiveness of BPD; (2) strengthening institutional resilience; and (3) increasing BPD contribution to the local economy (OJK, 2015).

This study is aimed to evaluate the efficiency and effectiveness of BPDs. The efficiency of BPDs is assessed based on their production and operational efficiency whereas the effectiveness of BPDs is evaluated based on their ability to implement development programs. This study seeks to answer the following questions:

1. What are the level of overall performance of BPDs?

2. What are the relative production efficiency and operational efficiency of the BPDs?

3. Are BPDs effective in implementing local economic development programs?

4. What is the classification of BPD in terms of efficiency and effectiveness? 


\section{LITERATURE REVIEW}

Data envelopment analysis (DEA) is a well extablished framework to asses the efficiency of banks (Asmild, Paradi, Reese, \& Tam, 2007, Tsolas, 2010). Barth, Lin, Ma, Seade, and Song (2013) use DEA to study the impact of bank regulation, supervision, and monitoring on bank efficiency. They find regulations that restrict bank activities are negatively associated with bank efficiency and stringen capital regulation is positively associated with bank efficiency. Kumar and Gulati (2010) investigate the efficiency and effectiveness of Indian banks by using DEA. They find positive correlation between effectiveness and performance indicators. Akomea-Frimpong (2017) finds that foreign banks are not necessarily more efficient than their domestic rivals. Erasmus and Makina (2014) showed that the global financial crisis did not affect the efficiency of the majority of the banks. Since the banks were efficient prior the crisis, it could be argued that their efficiency was one of the contributory factors for their resilience during the global financial crisis. All these studies show the importance assessing the efficiency of a bank in terms of costs, technical operations and all other areas which will help to create competitive advantage over their competitors.

In Indonesia, the study conducted by Abidin and Endri (2009) shows that large BPDs are more efficient than medium and small BPDs. Consistent with Abidin and Endri (2009), Sparta (2017) finds BPDs that have larger assets will have a higher level of efficiency. The results of these studies indicate that the size of BPD, as measured by asset, determines the efficiency of the BPD. Akbar and Djazuli (2014) conducted study that shows the efficiency of BPD tends to be higher in the era after regional autonomy when compared to the before regional autonomy period. The results of this study indicate that there is a relationship between provincial government regulations in the era of regional autonomy towards the level of BPD efficiency. Study conducted by Lisdayanti, Daniel and Anindita (2013) shows that BPDs have not been effective in supporting development in their region.

Previous studies by Abidin and Endri (2009), Sparta (2017), Akbar and Djazuli (2014), and Lisdayanti et al. (2013) on bank performance in Indonesia mostly focus on efficiency and do not investigate the correlation between efficiency and effectiveness. Therefore, there is a room to make a contribution by investigating the performance of bank and investigating efficiency and effectiveness relationship. It is interesting to explore whether an efficient BPD is also effective.

Rai (2008) defines performance audit as an audit conducted objectively and systematically against various types of evidence to assess the performance of auditees in terms of economy, efficiency and effectiveness, with the aim of improving performance and increasing public accountability. The Standard of State Financial Audit states that the objectives of a performance audit are to provide conclusions of the economic, efficiency and/ or effectiveness aspects of a state financial management, as well as to give recommendations to improve these aspects (BPK, 2017). The International Standards of Supreme Audit Institutions (ISSAI) 3000 defines performance audit as an independent examination of the efficiency and effectiveness of government activities, programs and organizations, taking into account economic aspects, with the aim of encouraging improvements (INTOSAI, 2016).

The result of a performance audit is the conclusion related to economy, efficiency and effectiveness (BPK RI, 2017). Mardiasmo (2009) describes economy as 
obtaining input with certain quality and quantity at the lowest price or minimizing input resources. Efficiency is defined as achieving maximum output with certain inputs or using the lowest input to achieve a certain output and effectiveness is defined as the level of output that reaches the set target (Mardiasmo, 2009).

There are various approaches to measure banking efficiency. Among others are production approach, intermediation approach, and operations approaches. The differences in each approaches can cause of input/output variable determination (Depren \& Depren, 2016). This study uses production and operation approaches, considering that both approaches are closer to the function of driving economic growth.

The production approach is used to measure the efficiency of a bank in managing savings accounts and loans. This approach defines output as a total of savings accounts. This approach also describes banks as service producers for depositors and borrowers using all available production factors such as labor and other physical capital. Production approach was initiated by Todhanakasem, Lynge, Primeaux, and Newboldet (1986) also Bell and Murphy (1968), which consider banks as producers of savings accounts for depositors and financing accounts for borrowers. This approach is suitable for measuring the internal efficiency of bank branches (Freixas \& Rochet, 1998). The operational approach compared costs incurred with incomes earned. This approach is equal to the concept of matching cost against revenue in accounting.

\section{RESEARCH METHODS}

This study is based on BPK audit report on the performance of BPDs. The audit was carried out on 13 BPDs covering the 2014 financial year and the first semester of 2015 . The audit used Data Envelopment Analysis (DEA) to find the efficiency of BPDs and qualitative analysis to investigate the effectiveness of BPDs in implementing local economic improvement programs.

DEA is basically developed on the basis of linear programming techniques. To measure production efficiency, the input variable consists of personnel expense, capital, and interest expense and the output variables consist of deposits and loans. Whereas for the measurement of operational efficiency, the input variable consists of personnel expense, interest expense, other operating expenses (excluded personnel expense and interest expense) and the output variable consists of interest income and other operating income.

BPK uses seven criterias to assess the effectiveness of BPDs. These criteria are (1) the BPD has adequate human resources (HR); (2) marketing communication (marketing activities) has responded to the development of bank business and dynamic competition; (3) BPD has adequate customer service quality; (4) BPD has adequate collected funds from third parties; (5) BPD sets a competitive interest rate; (6) BPD has an adequate capital structure; and (7) the BPD has provided sufficient loan (BPK, 2015a, 2015b, 2015c,2015d, 2015e, 2015f, 2015g, 2015h, 2015i，2015j, 2015k, 2015l, 2015m).

The auditor classified output of DEA into three categories: efficient, quite efficient and inefficient. While the effectiveness of BPDs is classified as effective, quite effective, not yet effective and ineffective. Measurement of BPDs performance is conducted by giving score on the level of efficiency and effectiveness. The level of efficiency would be rated on a scale of one to three while the level of effectiveness would be rated on scale 
of one to four as shown on table 1. Overall performance of a BPD is measured by using the formula (1):

Score $=\left(P E^{*} E F\right)+\left(O E^{*} E F\right)+(P E * O E)$

$\mathrm{PE}$ : production efficiency;

$\mathrm{EF}$ : effectiveness;

OE : operational efficiency.

Source: BPK (2015a).

\section{RESULTS AND DISCUSSION}

\section{Efficiency of BPDs}

DEA Program produces efficiency score for every BPD. The efficiency score is classified into three categories presented in table 2. A BPD will be classified as inefficient if the score of production efficiency is below
$81.60 \%$, quite efficient if the score is $81.61 \%$ $99.99 \%$, and efficient if the score is $100 \%$. Likewise, a BPD will be classified as inefficient if the score of operational efficiency is below $90.45 \%$, quite efficient if the score is $90.46 \%-99.99 \%$, and efficient if the score is $100 \%$.

Figure 1 presents the number of BPDs based on the level of operational and production efficiency. There are five BPDs that are inefficient from operational perspective and six BPDs that are inefficient from production perspective. On the other hand, there are only three BPDs that are efficient from production perspective and five BPDs that are efficient from operational perspective.

Table 1. Weight Assessment

\begin{tabular}{|c|c|c|c|}
\hline Efficiency & Weight & Effectiveness & Weight \\
\hline Efficient & 3 & Effective & 4 \\
\hline Quite Efficient & 2 & Quite Efective & 3 \\
\hline \multirow[t]{2}{*}{ Inefficient } & 1 & Not yet Effective & 2 \\
\hline & & Ineffective & 1 \\
\hline
\end{tabular}

Source: BPK (2015a)

Table 2. Efficiency Classification

\begin{tabular}{lrrrr}
\hline \multirow{2}{*}{ Classification } & \multicolumn{2}{c}{ Production Limit } & \multicolumn{2}{c}{ Operational Limit } \\
\cline { 2 - 5 } & \multicolumn{1}{c}{ Lower } & Upper & \multicolumn{1}{c}{ Lower } & \multicolumn{1}{c}{ Upper } \\
\hline Inefficient & $63.20 \%$ & $81.60 \%$ & $80.90 \%$ & $90.45 \%$ \\
\hline Quite Efficient & $81.61 \%$ & $99.99 \%$ & $90.46 \%$ & $99.99 \%$ \\
\hline Efficient & $100.00 \%$ & $100.00 \%$ & $100.00 \%$ & $100.00 \%$ \\
\hline
\end{tabular}

Source: BPK (2015a)

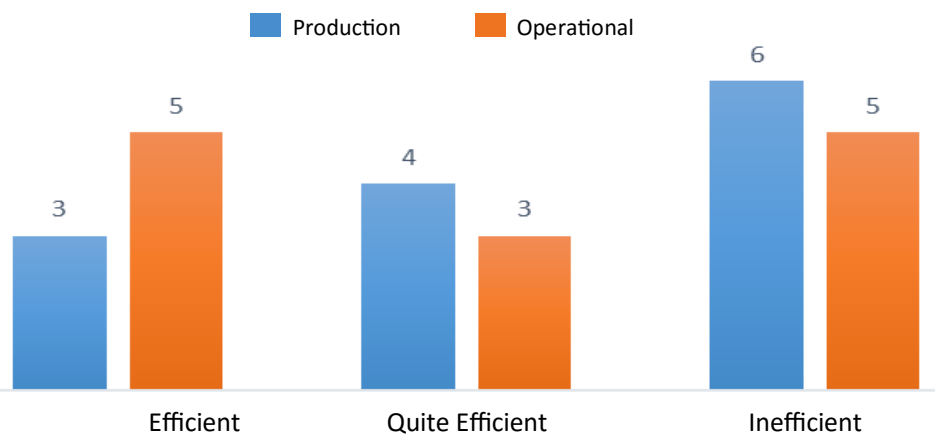

Figure 1. The Number of BPDs Based on the level of operational and production efficiency 
Based on BPK's audit reports (BPK, 2015a, 2015b, 2015c, 2015d, 2015e, 2015f, 2015g, 2015h, 2015i, 2015j, 2015k, 2015l, 2015m), the causes of production inefficiency are the lack of deposits outside of local government funds, non-optimal loan distribution, nonoptimal investment placement, high labor costs, and high interest costs in raising funds. While the causes of operational inefficiency are high labor costs, high interest costs in raising funds, and high general also administrative costs.

\section{The Effectiveness of BPDs}

The effectiveness classification on BPK's audit reports consist of four tier, as presented in table 3 .

Table 3. Effectiveness Classifications

\begin{tabular}{lcc}
\hline \multirow{2}{*}{ Classification } & \multicolumn{2}{c}{ Production Limit } \\
\cline { 2 - 3 } & Lower & Upper \\
\hline Ineffective & 0 & 24.99 \\
\hline Not yet Effective & 25 & 49.99 \\
\hline Quite Effective & 50 & 74.99 \\
\hline Effective & 75 & 100 \\
\hline
\end{tabular}

Source: BPK (2015a)

The level of BPD effectiveness in implementing programs that can encourage local economic growth can be seen in figure 2. As shown on the figure 2 there is only one BPD that is effective. The majority of BPDs fall into category quite effective (7 BPDs) and

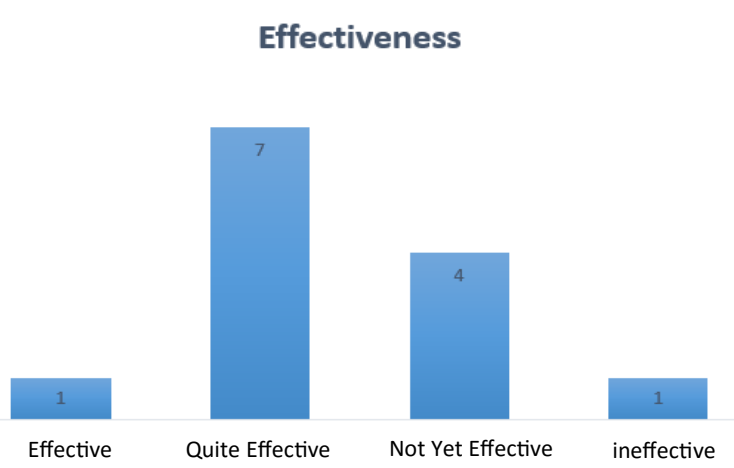

Figure 2. Effectiveness Level of BPD in Implementing Programs that Can Encourage Local Economic Growth not yet effective (4 BPDs). The causes of ineffectiveness identified are (1) the lack of optimal involvement of BPDs in the storage of Local Government Cash Accounts, Local Public Service (BLUD) Accounts and BUMD Accounts; (2) the less optimal role of the BPD in the development and capacity building of the Micro, Small, and Medium Enterprise (MSME) segments; and (3) the inadequate role of the BPD in the implementation or realization of capital expenditures.

\section{Is An Efficient BPD Also Effective?}

The weighting results of production efficiency, operational efficiency and subsequent effectiveness are included in the scatter plot to find out which BPD has a higher efficiency and effectiveness level than average. Scatter plots of production effeciency and effectiveness can be seen in the figure 3 .

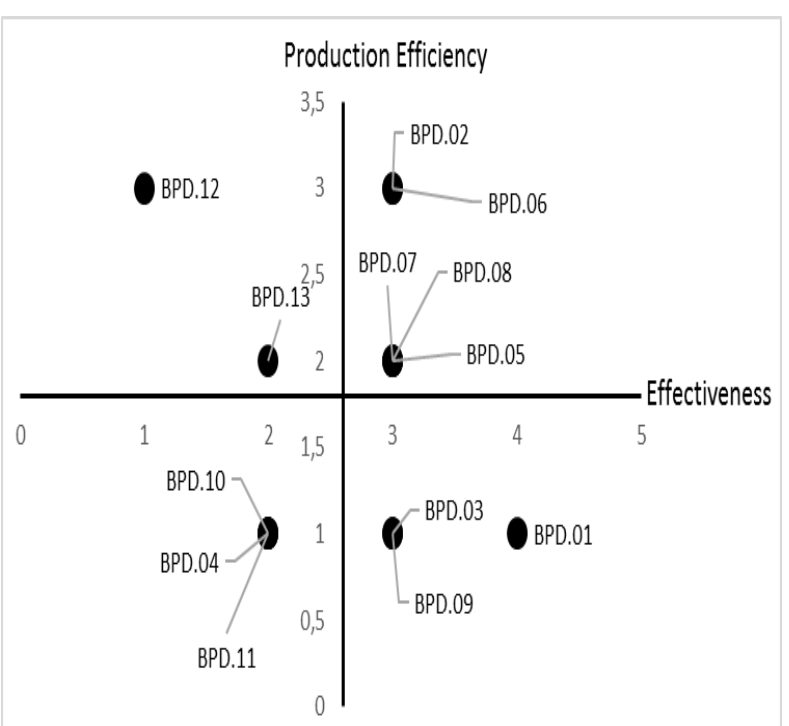

Figure 3. Scatter Plot Effectiveness and Production Efficiency

As shown in figure 3, there are five BPDs in the first quadrant. These BPDs (BPD.02, BPD.05, BPD.06, BPD.07, BPD.08) are considered effective and efficient in production. In contrast, there are two BPDs (BPD.12 and BPD.13) that are efficient in production but not effective. 
Scatter plots of operational effeciency and effectiveness can be seen in the figure 4 . There are two BPDs in the first quadrant. These BPDs (BPD.05 and BPD.09) are considered effective and efficient in their operational activities. In contrast, there are three BPDs (BPD.04, BPD.10, BPD.11) that are efficient in operational activities but not effective.

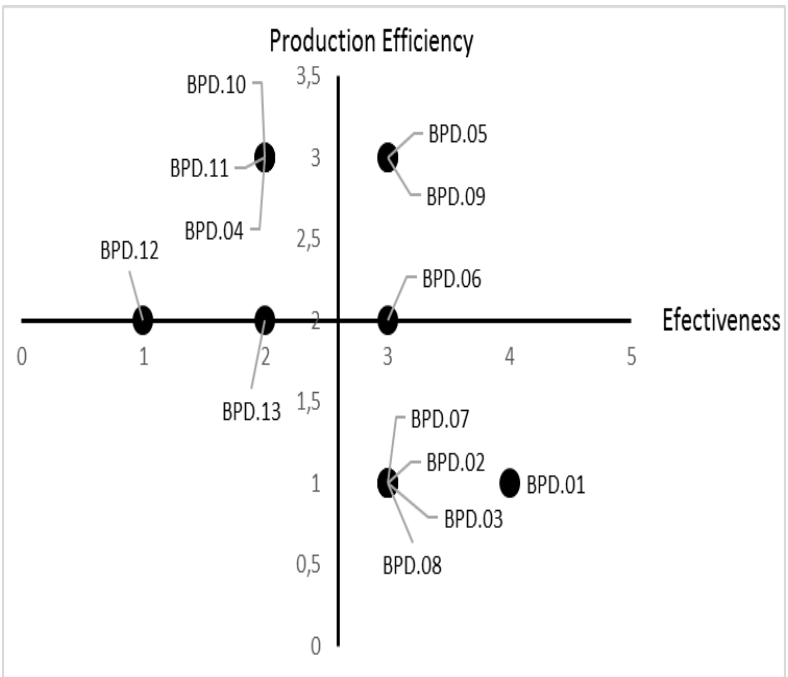

Figure 4. Scatter Plot Effectiveness and Production Efficiency

Scatter plots of production efficiency and operational effeciency can be seen in the figure 5 . Figure 5 shows there is only one $\mathrm{BPD}$ in the first quadrant. This means there is only one BPD is considered efficient in its operational and production activities. In

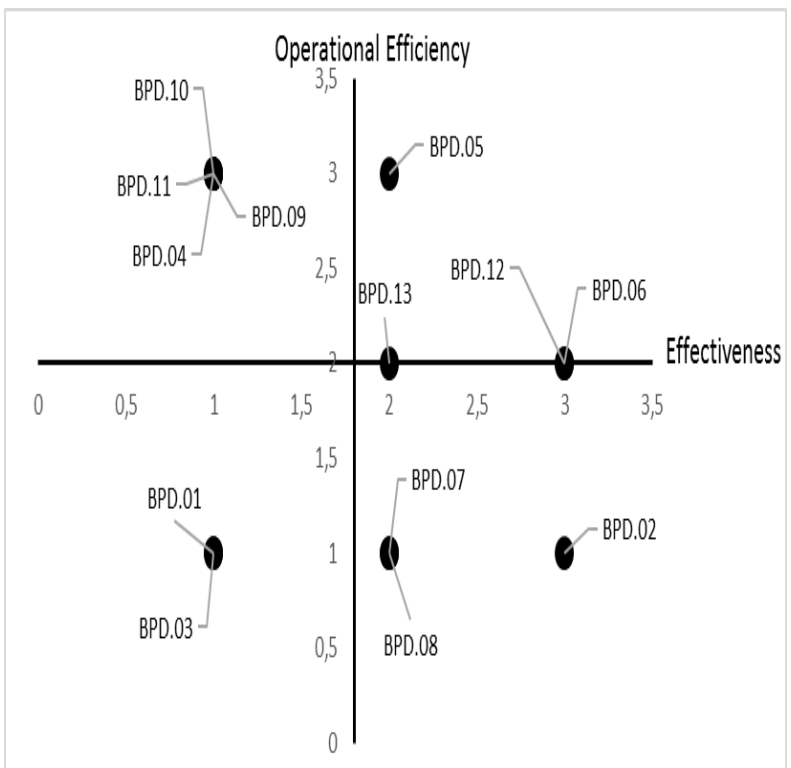

Figure 5. Scatter Plot Effectiveness and Operational Efficiency contrast, there are two BPDs (BPD.01 and BPD.03) that are inefficient in operational and production activities.

\section{Overall Performance of BPDs}

This study is using Spider Diagram and the formula to measure the overall performance of BPDs. The spider diagram shows the comparison between operational efficiency, production efficiency, and effectiveness. The BPD's production and operational efficiency based on DEA Program and the level of effectiveness based on BPK's audit reports is presented in figure 6 .

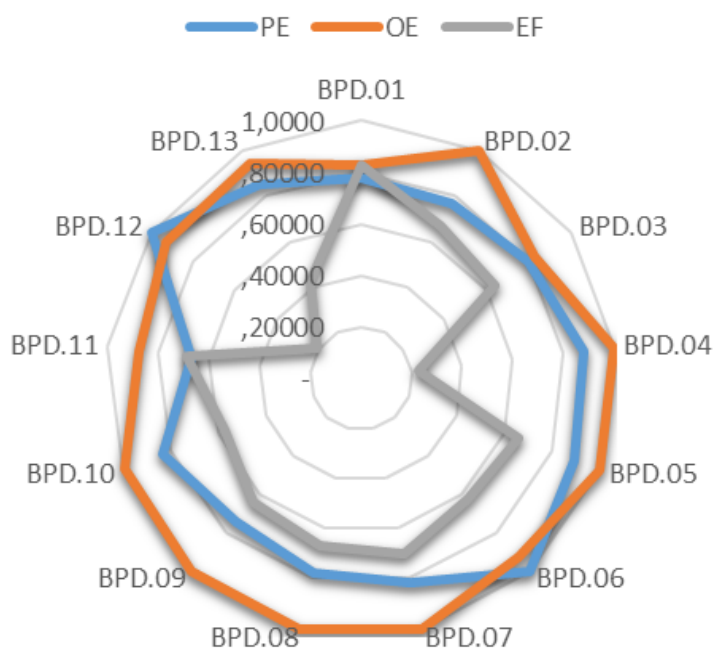

Figure 6. Comparison of Operational Efficiency, Production Efficiency, and Effectiveness

Generally, the value of operational efficiency is higher than production efficiency and effectiveness. However, a BPD that has a high score of operational efficiency is not always has a high score of production efficiency and effectiveness. The total score of effectiveness and efficiency is calculated using formula (1) and the result is presented in figure 7.

There are two BPDs (BPD.05 and BPD.06) that have the highest score. Based on the three scatter plots analysis (figure 3, figure 4 and figure 5), BPD.05 is in the first quadrant which shows that BPD.05 has a higher level of effectiveness and efficiency than the other 
BPDs. Therefore, BPD.05 can be used as a reference for other BPDs in an effort to improve their effectiveness and efficiency.

Based on the score produced by DEA Program, BPD.05 gets a production efficiency score of 0.896 so that BPD.05 falls into quite efficient category. BPD.05 did not achieve efficient level because:

1. BPD.05 did not have performance-based human resources planning and policies;

2. BPD.05 has not have a robust marketing planning;

3. Determination and awarding of deposit interest rates at BPD.05 has not complied with the provisions and results in increasing the ratio of operating costs to operating income;

4. Low Cost Deposit activities on BPD.05 were not sufficient;

5. High dependency to a few high profile depositors;

6. Giving special interest rates to local government deposit accounts above market interest rate.

BPD.05 gets an effectiveness level of $66 \%$ so that BPD.05 is included in the quite effective category. BPD.05 did not achieve effective level because:

1. BPD.05 has not collected information about forecasting of cash deposit and withdrawl from local government treasurer;

2. The management of regional cash accounts (regonal government treasurer/ treasurer of receipt/treasurer of expenditure), cash accounts of BLUD and cash accounts of BUMD is not optimum;

3. The development programs in strengthening the capacity of the MSME segment have not been fully supported by adequate Standard Operating Procedures (SOP) and human resources;

4. The role of BPD.o5 in carrying out the development and strengthening of the capacity of the MSME segment and other productive segments has not been optimum;

5. BPD.05 has not been optimum in planning its activities to participate in financing local government capital expenditure;

6. BPD.05 has not been optimum in financing local government capital expenditure.

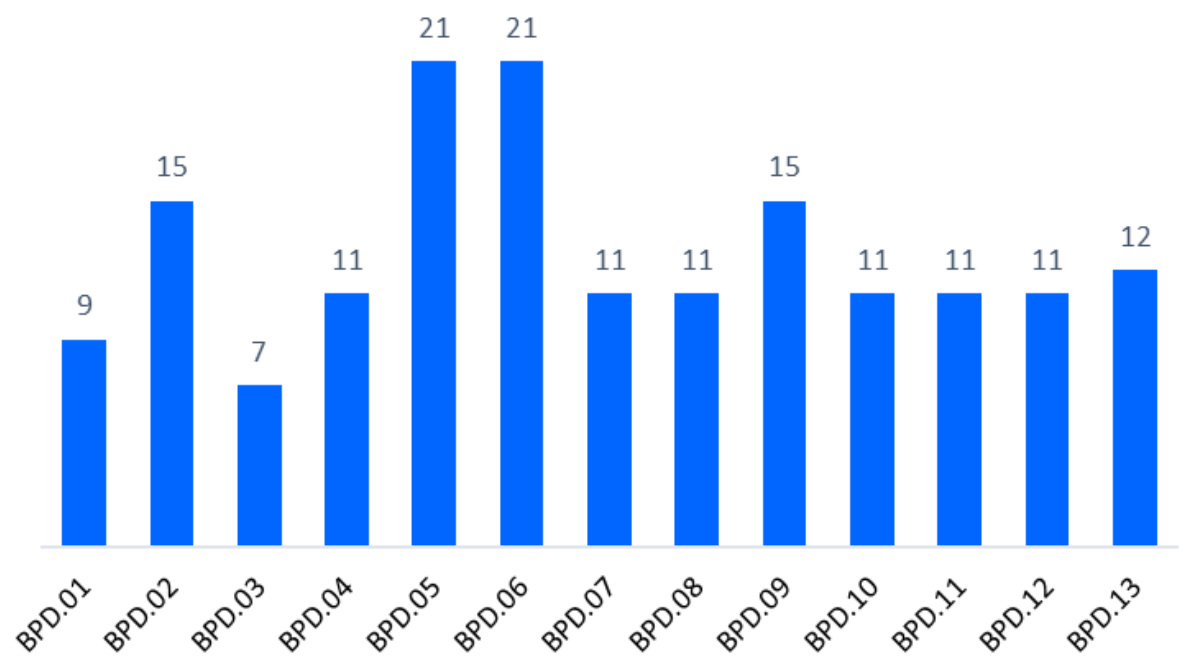

Figure 7. Score of Effectiveness, Production and Operational Efficiency 


\section{CONCLUSION}

There is a BPD that is relatively higher in efficiency compared to other BPDs but has not been effective individually. Internal improvement needs to be conducted so that the relative efficiency obtained is in line with individual effectiveness. In total assessment, the BPD obtained the highest efficiency and effectiveness values could be used as a reference for other BPDs to make improvements and become a regional champion in their respective regions.

\section{REFERENCES}

Abidin, Z., \& Endri. (2009). Kinerja efisiensi teknis Bank Pembangunan Daerah: Pendekatan data envelopment analysis. Jurnal Akuntansi dan Keuangan, 11 (1), 21-29. doi: 10.9744/jak.11.1.pp.\% 2021-29.

Akbar, B., \& Djazuli, A. (2014). Efisiensi BPD pada era sebelum dan sesudah otonomi daerah. Paper presented at The IFABS International Conference, Lisbon, Portugal.

Akomea-Frimpong, I. (2017). Review of Empirical Studies on Bank Efficiency In Emerging Economies. Retrieved from https://www.researchgate.net/ publication/322144466_Review_of_ Empirical_Studies_on_Bank_ Efficiency_in_Emerging_Economies.

Asmild, M., Paradi, J. C., Reese, D. N., \& Tam, F. (2007). Measuring overall efficiency and effectiveness using DEA. European Journal of Operational Research, 178(1), 305-321. doi:10.1016/ j.ejor.2006.01.014.

Barth, J., Lin, C., Ma, Y., Seade, J., \& Song, F. M. (2013). Do bank regulation, supervision and monitoring enhance or impede bank efficiency?. Journal of Banking \& Finance, 37(8), 2879-2892.

Bell, R.W., \& Murphy, N. B. (1968). Costs in commercial banking: A quantitative analysis of bank behavior and its relation to bank regulation. Research Report No. 41. Boston: Federal Reserve Bank of Boston.

BPK RI. (2015a). Laporan Hasil Pemeriksaan kinerja efisiensi bank dan efektivitas program bank dalam rangka peningkatan perekonomian daerah pada BPD Bali Tahun Buku 2014 dan Semester I 2015. Jakarta: BPK RI.

BPK RI. (2015b). Laporan Hasil Pemeriksaan kinerja efisiensi bank dan efektivitas program bank dalam rangka peningkatan perekonomian daerah pada BPD Jambi Tahun Buku 2014 dan Semester I 2015. Jakarta: BPK RI.

BPK RI. (2015c). Laporan Hasil Pemeriksaan kinerja efisiensi bank dan efektivitas program bank dalam rangka peningkatan perekonomian daerah pada BPD Kalimantan Barat Tahun Buku 2014 dan Semester I 2015. Jakarta: BPK RI.

BPK RI. (2015d). Laporan Hasil Pemeriksaan kinerja efisiensi bank dan efektivitas program bank dalam rangka peningkatan perekonomian daerah pada BPD Kalimantan Selatan Tahun Buku 2014 dan Semester I 2015. Jakarta: BPK RI.

BPK RI. (2015e). Laporan Hasil Pemeriksaan kinerja efisiensi bank dan efektivitas program bank dalam rangka peningkatan perekonomian daerah pada BPD Lampung Tahun Buku 2014 dan Semester I 2015. Jakarta: BPK RI.

BPK RI. (2015f). Laporan Hasil Pemeriksaan kinerja efisiensi bank dan efektivitas program bank dalam rangka pening- 
katan perekonomian daerah pada BPD Maluku dan Maluku Utara Tahun Buku 2014 dan Semester I 2015. Jakarta: BPK RI.

BPK RI. (2015g). Laporan Hasil Pemeriksaan kinerja efisiensi bank dan efektivitas program bank dalam rangka peningkatan perekonomian daerah pada BPD Nusa Tenggara Barat Tahun Buku 2014 dan Semester I 2015. Jakarta: BPK RI.

BPK RI. (2015h). Laporan Hasil Pemeriksaan kinerja efisiensi bank dan efektivitas program bank dalam rangka peningkatan perekonomian daerah pada BPD Nusa Tenggara Timur Tahun Buku 2014 dan Semester I 2015. Jakarta: BPK RI.

BPK RI. (2015i). Laporan Hasil Pemeriksaan kinerja efisiensi bank dan efektivitas program bank dalam rangka peningkatan perekonomian daerah pada BPD Sulawesi Selatan dan Sulawesi Barat Tahun Buku 2014 dan Semester I 2015. Jakarta: BPK RI.

BPK RI. (2015j). Laporan Hasil Pemeriksaan kinerja efisiensi bank dan efektivitas program bank dalam rangka peningkatan perekonomian daerah pada BPD Sulawesi Tengah Tahun Buku 2014 dan Semester I 2015. Jakarta: BPK RI.

BPK RI. (2015k). Laporan Hasil Pemeriksaan kinerja efisiensi bank dan efektivitas program bank dalam rangka peningkatan perekonomian daerah pada BPD Sulawesi Tenggara Tahun Buku 2014 dan Semester I 2015. Jakarta: BPK RI.

BPK RI. (2015l). Laporan Hasil Pemeriksaan kinerja efisiensi bank dan efektivitas program bank dalam rangka peningkatan perekonomian daerah pada BPD Sumatera Barat Tahun Buku 2014 dan Semester I 2015. Jakarta:
BPK RI.

BPK RI. (2015m). Laporan Hasil Pemeriksaan kinerja efisiensi bank dan efektivitas program bank dalam rangka peningkatan perekonomian daerah pada BPD Sumatera Selatan Tahun Buku 2014 dan Semester I 2015. Jakarta: BPK RI.

BPK RI. (2017). Standar Pemeriksaan Keuangan Negara. Jakarta: BPK.

Depren, K. S., \& Depren, O. (2016). Measuring Efficiency and Total Factor Productivity using Data Envelopment Analysis: An Empirical Study from Banks of Turkey. International Journal of Economics and Financial Issues, 6(2), 711717.

Erasmus, C., \& Makina, D. (2014). An empirical study of bank efficiency in South Africa using the standard and alternative approaches to Data Envelopment Analysis (DEA). Journal of Economics and Behavioral Studies, 6(4), 310-317.

Freixas, X., \& Rochet, J. C. (1998). Microeconomics of banking. Cambridge: Mit Press.

Investor Daily Indonesia. (August, 2018). Per Mei 2018, Aset BPD seluruh Indonesia capai Rp 641,19 triliun. Retrieved from https://investor.id/archive/permei-2018-aset-bpd-seluruh-indonesiacapai-rp-64119-triliun.

INTOSAI. (2016). The Intermational Standards of Supreme Audit Institutions 30oo: Standard for Performance Auditing. Vienna: INTOSAI.

Kumar, S., \& Gulati, R. (2010). Measuring efficiency, effectiveness and performance of Indian public sector banks. International Journal of Productivity and Performance Management, 59(1), 51-74. doi: 10.1108/174104010110 06112.

Law of The Republic of Indonesia Number 15 
of 2004 on The Examination of Management and Responsibility for State Finance (Undang-Undang Nomor 15 Tahun 2004 tentang Pemeriksaan Pengelolaan dan Tanggung Jawab Keuangan Negara).

Lisdayanti, A., Daniel, R. D., \& Anindita, W. (2013). Efektivitas Kinerja BPD Terhadap Pertumbuhan Ekonomi Daerah. Paper presented at Psikologi, Ekonomi, Sastra, Arsitektur \& Teknik Sipil, Bandung, Indonesia. Retrieved from https://ejournal.gunadarma.ac.id/ index.php/pesat/article/ view/1231/o.

Mardiasmo. (2009). Akuntansi sektor publik. Yogyakarta: Penerbit Andi.

OJK. (2015). Program transformasi BPD: Menjadi bank yang kompetitif, kuat, dan kontributif bagi pembangunan daerah. Retrieved from https:// www.ojk.go.id/id/kanal/perbankan/ berita-dan-kegiatan/publikasi/Pages/ Program-Transformasi-BPD.aspx.

Rai, I. G. A. (2008). Audit kinerja pada sektor publik konsep praktek studi kasus. Jakarta: Penerbit Salemba Empat.

Sparta. (2017). Analisis Pengaruh Efisiensi dan Kecukupan Modal terhadap Kinerja Keuangan pada Bank Pembangunan Daerah di Indonesia. Jurnal Ekonomi dan Bisnis, 2o(1). doi: 10.24914/ jeb.v20i1.462.

Statistics Indonesia. (2018). Financial Statistics of State-Owned Enterprises and Regional-Owned Enterprises 2017. Jakarta: Statistics Indonesia.

The 1945 Constitution of Republic of Indonesia (Undang-Undang Dasar Republik Indonesia Tahun 1945). Retrieved from http://peraturan.go.id/inc/ view/11e58ce2b70ac2co94ce313132313 436.html.

Todhanakasem, W., Lynge, M. J., Primeaux, W. J. Jr., \& Newbold, P. (1986). Econo- mies of scale and organization efficiency in banking. Managerial and Decision Economics, 7(4), 255-261.

Tsolas, I. E. (2010). Modeling bank branch profitability and effectiveness by means of DEA. International Journal of Productivity and Performance Management, 59(5), 432-451. doi:10.1108/17410401011052878. 